\title{
Hubungan Cara Belajar dengan Minat Belajar Siswa Kelas VIII MTs Ash-Shohibiyah Bangun Purba Kabupaten Rokan Hulu Provinsi Riau
}

\author{
Meriyanti * \\ * MTs Ash-Shohibiyah Bangun Purba
}

\begin{tabular}{l} 
INFO ARTIKEL \\
\hline Riwayat Artikel: \\
Diterima: 6 Maret 2018 \\
Disetujui: 10 Juni 2018
\end{tabular}

\section{Kata kunci:}

Strategi Pembelajaran

Seni Musik

Prestasi Belajar

\author{
Alamat Korespondensi: \\ Meriyanti, \\ MTs Ash-Shohibiyah Bangun Purba \\ Bangun Purba, Kabupaten Rokan Hulu \\ E-mail: meriyanti@gmail.com
}

\begin{abstract}
ABSTRAK
Abstract: Based on the results of the research that has been obtained about the strategy of learning music art to improve student achievement in SMP Negeri 13 Pekanabaru, some conclusions can be drawn such as the following: Learning preparation strategies. The main step shown by the teacher with the preparation of lesson plans that is oriented towards the curriculum and syllabus used. The RPP lists the strategies and methods of learning that are applied. Management strategies in each class. Teachers teach with different methods for each class because each class has different characters. Strategy for using learning media. The teacher leads to preparation and utilizing media and learning tools that are in accordance with the material and facilities available in the school's music lab. Strategy approach to motivate students. To motivate students, the teacher takes a personal, group and functional approach. The strategy of motivational approaches by teachers is supported by school participation by providing a means of supporting good learning. Strategy for evaluation and value taking. In this strategy the teacher holds a score not only in the UTS and UAS, but by holding a daily test after the completion of Basic Competence. The teacher also conducts assessments at any time in the learning process takes place by looking at the students' responses, seeing the answers to oral questions from the teacher. The results of the evaluation will be followed up by the teacher as the stage of learning learning. Strategies for developing students' musical art learning experiences. In this strategy the teacher develops student learning activities, by increasing the learning activities of music practice compared to learning music theory, but by not putting aside the theory that remains present throughout the course of learning. In addition, there are also many activities or activities supporting the achievement of students' musical arts achievements at school
\end{abstract}

\section{LATAR BELAKANG}

Dalam keseluruhan proses pendidikan di sekolah, kegiatan belajar merupakan kegiatan yang paling pokok. Ini berarti berhasil tidaknya pencapaian tujuan pendidikan banyak bergantung kepada bagaimana proses belajar yang dialami oleh murid sebagai siswa. Apabila siswa tidak memiliki minat dalam belajar maka hasil belajar yang diperoleh tidak akan bisa optimal. Belajar merupakan proses manusia untuk mencapai berbagai macam kompetensi, keterampilan, dan sikap. Belajar dimulai sejak manusia lahir sampai akhir hayat. Kemampuan manusia untuk belajar merupakan karakteristik penting yang membedakan manusia dengan makhluk hidup lainnya. Belajar mempunyai keuntungan, baik bagi individu maupun bagi masyarakat. Bagi individu, 
kemampuan untuk belajar secara terus-menerus akan memberikan kontribusi Dengan pengembangan kualitas hidupnya. Sedangkan bagi masyarakat, belajar mempunyai peran yang penting dalam mentransmisi budaya dan pengetahuan dari generasi ke generasi. Belajar merupakan aktivitas yang dilakukan seseorang untuk mendapatkan perubahan dalam dirinya melalui pelatihan-pelatihan atau pengalaman-pengalaman. Dengan demikian, belajar membawa perubahan bagi si pelaku. Baik perubahan pengetahuan, sikap, maupun keterampilan.

Belajar adalah suatu kegiatan yang kita lakukan untuk memperoleh sejumlah ilmu pengetahuan. Dalam belajar, kita tidak bisa melepaskan diri dari beberapa hal yang dapat mengantarkan kita berhasil dalam belajar. Banyak orang yang belajar dengan susah payah, tetapi tidak mendapatkan hasil apa-apa hanya kegagalan yang ditemui. Penyebabnya tidak lain karena belajar tidak teratur, tidak disiplin, dan kurang semangat, tidak tahu bagaimana cara berkonsentrasi dalam belajar, mengabaikan masalah pengaturan waktu dalam belajar, kurangnya minat dalam belajar, dan tidak adanya motivasi dalam diri individu tersebut.

Minat adalah sesuatu pemusatan perhatian yang tidak disengaja yang terlahir dengan penuh kemauannya dan yang tergantung dari bakat dan lingkungan. Minat berperan sangat penting dalam kehidupan siswa dan mempunyai dampak yang besar Dengan sikap dan perilaku. Siswa yang berminat Dengan kegiatan belajar akan berusaha lebih keras dibandingkan siswa yang kurang berminat dalam belajarnya. Minat sangat besar Hubungannya Dengan hasil belajar, karena apabila bahan pelajaran yang dipelajari tidak sesuai dengan minat, siswa tidak akan belajar dengan baik sebab tidak menarik baginya. Siswa akan malas belajar dan tidak akan mendapatkan kepuasan dari pelajaran itu. Bahan pelajaran yang menarik minat siswa, lebih mudah dipelajari sehingga dapat meningkatkan prestasi belajar.

Akan tetapi di era globalisasi ini para siswa mengalami minat belajar yang rendah dikarenakan jenuh dalam belajarnya, karena pergaulan, motivasi belajar yang rendah, kesehatan fisik, kompetensi/kemamapuan yang dimiliki siswa, fasilitas yang dimiliki, jarang masuk sekolah, tidak tertarik pada mata pelajaran tersebut dan sebagainya. Berdasarkan observasi dan wawancara dengan guru pembimbing di MTs Ash-Shohibiyah Bangun Purba mempunyai masalah minat belajar yang kurang, hal ini di sebabkan oleh beberapa faktor antara lain: masih rendahnya prosentase untuk melanjutkan ke sekolah yang lebih tinggi sehingga siswa tidak mempunyai motivasi untuk belajar lebih giat lagi, kesadaran orang tua akan pentingnya pendidikan bagi anak-anaknya, letak/ lokasi sekolah yang jauh dari jalan atau lokasi yang masuk ke dalam desa sehingga menyebabkan tidak banyak siswa yang mau sekolah di MTs Ash-Shohibiyah Bangun Purba.

Upaya yang dilakukan oleh pihak sekolah di MTs Ash-Shohibiyah Bangun Purba melalui peran guru pembimbing dalam membantu sisiwa untuk mengubah dan mengembangkan minat belajar yang masih rendah pada siswa, kebanyakan hanya dengan menggunakan layanan konseling individual. Upaya tersebut kurang mendapat hasil optimal, karena layanan konseling individual itu dilakukan secara perseorangan sehingga tidak efektif diberikan kepada siswa yang jumlahnya cukup banyak. Prestasi belajar yang baik bukan hanya dihasilkan dari perumusan tujuan pembelajaran yang baik tetapi dipengaruhi oleh komponen-komponen yang lain, dan terutama bagaimana aktivitas siswa sebagai subjek belajar (Sardiman, 2010: 49). Maka penulis melakukan penelitian untuk mengetahui prestasi belajar siswa di antaranya adalah memilih dan menggunakan cara belajar yang efektif.

Cara belajar merupakan suatu cara bagaimana siswa melaksanakan kegiatan belajar misalnya bagaimana mereka mempersiapkan belajar, mengikuti pelajaran, aktivitas belajar mandiri yang dilakukan, pola belajar mereka, cara mengikuti ujian. Kualitas cara belajar akan menentukan kualitas hasil belajar yang diperoleh. Cara belajar yang baik akan menyebabkan berhasilnya belajar, sebaliknya cara belajar yang buruk akan menyebabkan kurang berhasil atau gagalnya belajar (The Liang Gie, 1984). Buruknya cara belajar merupakan salah satu faktor penyebab rendahnya hasil belajar sehingga menyebabkan menurunnya mutu pendidikan. Slameto (2002) mengemukakan bahwa faktor cara belajar yang buruk merupakan penyebab masih cukup banyaknya siswa yang sebenarnya pandai tetapi hanya meraih prestasi yang tidak lebih baik dari siswa yang sebenarnya kurang pandai tetapi mampu meraih prestasi yang tinggi karena mempunyai cara belajar yang baik. Aspek lain yang perlu mendapat perhatian berkaitan dengan cara belajara siswa adalah karakteristik mata diklat yang dipelajari. Setiap 
82 Instructional Development Journal (IDJ), Vol. 1, No. 2, Desember 2018, Hal. 81-87

mata diklat memiliki sifat maupun ciri khusus yang berbeda dengan mata diklat lainnya. Menurut Winkel (1996: 245) dilihat dari segi sasaran belajar karakteristik mata diklat dibedakan menjadi 1) Menuntut kemampuan pengetahuan, 2) Mengutamakan aspek sikap, 3) Mengutamakan aspek ketrampilan. Cara belajar bukanlah satusatunya variabel yang berhubungan dengan prestasi belajar yang dicapai oleh siswa. Masih banyak variabel lain yang mempengaruhi antara lain motivasi dan minat belajar, lingkungan, sarana, prasarana, guru, dan lain sebagainya. Jadi dalam penelitian ini hanya meneliti tentang cara belajar siswa, sehubungan dengan masih rendahnya prestasi belajar yang dicapai oleh siswa.

\section{METODE}

Jenis penelitian yang digunakan dalam penelitian ini adalah penelitian expost facto atau disebut dengan after the fact. Sudjana dan Ibrahim (2007: 60) mengatakan bahwa Penelitian ex post facto dimulai dengan mendeskripsikan situasi sekarang yang diasumsikan sebagai akibat dari faktor-faktor yang telah terjadi atau bereaksi sebelumnya. Penelitian ini bertujuan untuk menentukan ada tidaknya hubungan antara Variabel bebas (X) dan variable terikat (Y). Sedangakan untuk menghitung besarnya korelasi digunakannya statistik. Variabel penelitian ini dapat digambarkan sebagai berikut : 1) Variabel terikat atau dependent variable (Y) adalah minat belajar siswa MTs Ash-Shohibiyah Bangun Purba Kabupaten Rokan Hulu. Sedangkan Variabel bebas atau independent variable $(\mathrm{X})$ adalah cara belajar.

Prosedur penelitian yang dapat peneliti uraikan adalah sebagai berikut: persiapan penelitian yaitu mengadakan pendekatan dan konsultasi kepada guru pembimbing dan kepala sekolah di MTs Ash-Shohibiyah Bangun Purba tentang rencana penelitian yang akan dilakukan di sekolah, mempersiapkan surat ijin penelitian yang akan diserahkan kepada kepala sekolah MTs Ash-Shohibiyah Bangun Purba. Membuat jadwal penelitian yang meliputi pembuatan instrumen, analisis hasil skala untuk dijawab responden serta menganalisis uji instrumen sebagai alat ukur variabel. Mempersiapkan instrumen alat pengumpul data termasuk membuat kisikisi pengembangan instrumen peserta analisis instrumen yang sesuai dengan aspek yang akan diungkap serta perhitungan skornya, menentukan variabel yang akan diteliti, menyusun dan mengadakan instrumen untuk selanjutnya disampaikan responden. Pelaksanaan penelitian adalah mempersiapkan instrumen guna mengadakan instrumen penelitian alat pengumpulan data dalam penelitian ini adalah angket penelitian yang telah disediakan, untuk diisi oleh siswa. Setelah menganalisis hasil dari angket, langkah selanjutnya adalah memberikan cara belajar yang efektif kepada kelas yang dijadikan sampel penelitian.

Dalam penelitian ini yang menjadi populasi penelitian adalah seluruh siswa kelas VIII di MTs AshShohibiyah Bangun Purba Tahun Pelajaran 2013/2014, berjumlah 66 siswa yang terbagi dalam laki-laki dan perempuan yaitu 40 siswa dan 26 siswa. Oleh karena jumlah populasi kurang dari 100, maka pada penelitian ini digunakan sampel penuh sehingga seluruh populasi digunakan untuk diambil sebagai sampel dalam penelitian ini.

Teknik pengumpulan data dalam penelitian ini secara berurutan menurut keutamaan dan skala prioritasnya adalah sebagai berikut: angket, dan dokumentasi. Sedangkan analisis data yang digunakan terdiri dari 2, yaitu: 1) Analisis deskriptif digunakan untuk menentukan besar rata- rata (Mean), distribusi frekuensi, dan pembuatan histogram dari variabel penelitian yang mencakup cara belajar dan minat belajar siswa kelas VIII MTs Ash-Shohibiyah Bangun Purba Kabupaten Rokan Hulu; dan 2) Analisis inferensial pada penelitian ini dilakukan dengan tujuan agar prestasi penelitian dapat dibuat kesimpulan pengujian hipotesis secara generalisasi. Untuk keperluan analisis data dalam mengetahui besar kontribusi variabel independen terhadap variabel dependen diolah dengan uji korelasi Product Moment melalui Program SPSS Versi 18.00 for windows. Sebelum melakukan analisis data ada syarat yang harus dilakukan, yaitu: uji normalitas dan uji homogenitas.

\section{HASIL DAN PEMBAHASAN}

Pengolahan data kajian penelitian menggunakan pengujian statistik dengan analisis korelasi Product Moment. Namun sebelum itu, peneliti melakukan uji persyaratan analisis sehingga hasilnya dapat digunakan untuk menarik kesimpulan. Uji persyaratan yang dimaksud mencakup normalitas, homogenitas dan linieritas. 
Berdasarkan uji normalitas diperoleh informasi bahwa nilai signifikan untuk variable cara belajar sebesar 0,200* dan variable minat belajar sebesar $0,200^{*}$. Nilai signifikan ini lebih besar dari taraf signifikan $\alpha=0,05$. Dengan demikian, dapat dikatakan bahwa masing-masing variable berdistribusi normal. Sedangkan untuk uji homogenitas, varians skor cara belajar dan minat belajar siswa yang diperoleh adalah lebih besar dari taraf signifikansi $\alpha=0,05(0,387>0,05)$. Selanjutnya disimpulkan bahwa cara belajar dan minat belajar siswa adalah homogen. Selanjutnya, berdasarkan hasil analisis maka dapat digambarkan bahwa nilai signifikansi yang diperoleh sebesar 0,000. Karena signifikansi kurang dari 0,05 maka dapat disimpulkan bahwa antara cara belajar dan minat belajar siswa terdapat hubungan yang linier.

Hipotesis yang diajukan dalam penelitian adalah "ada hubungan layanan bimbingan kelompok dengan minat belajar siswa kelas VIII MTs Ash-Shohibiyah Bangun Purba Kabupaten Rokan Hulu Provinsi Riau”. Berdasarkan hipotesis penelitian tersebut, maka hipotesis nol (Ho) yang diuji adalah "tidak ada hubungan layanan bimbingan kelompok dengan minat belajar siswa kelas VIII MTs Ash-Shohibiyah Bangun Purba Kabupaten Rokan Hulu Provinsi Riau. Berdasarkan hasil perhitungan diperoleh bahwa nilai signifikansi adalah 0,033 yang lebih kecil dari nilai $a=0,05$ dan nilai $\mathrm{r}_{\text {hitung }}$ adalah $\mathbf{0 , 2 6 3 ^ { * }}$ pada kategori "sedang". Harga koefisien tersebut selanjutnya diuji signifikansinya dengan membandingkan $\mathrm{r}_{\text {tabel }}$ untuk $\mathrm{n}=66$ pada taraf $5 \%$ maka $\mathrm{r}_{\text {tabel }}=$ 0,254 , di mana nilai $r_{\text {hitung }}>r_{\text {tabel }}(0,236>0,224)$ dan nilai signifikansi yang diperoleh lebih kecil dari 0,05 . Dengan demikian, Ha diterima yaitu ada hubungan layanan bimbingan kelompok dengan minat belajar siswa kelas VIII MTs Ash-Shohibiyah Bangun Purba Kabupaten Rokan Hulu Provinsi Riau. Sementara kontribusi cara belajar dalam meningkatkan minat belajar siswa sebesar 11,36\%.

Dalam penelitian ini hipotesis kerja yang penulis laksanakan terbukti kebenarannya. Yaitu berdasarkan analisis korelasi Product Moment di atas maka dapat disimpulkan bahwa hipotesis alternatif penelitian yang berbunyi "ada hubungan cara belajar dengan minat belajar siswa kelas VIII MTs Ash-Shohibiyah Bangun Purba Kabupaten Rokan Hulu Provinsi Riau, diterima kebenarannya. Berdasarkan analisis data bahwa cara belajar berkontribusi secara signifikan sebesar 9,73\% terhadap prestasi belajar siswa. Hal ini sesuai dengan pendapat Oemar Hamalik yang menyatakan bahwa cara dan kebiasaan belajar yang tepat akan menentukan hasil yang memuaskan, sebaliknya cara belajar yang buruk akan memberikan hasil yang kurang memuaskan (Oemar Hamalik, 1994: 1). Terdapat hubungan tersebut disebabkan banyak hal antara lain, cara belajar siswa sudah sejalan dengan cara belajar yang diharapkan dalam ajaran Islam. Padahal, cara belajar siswa yang baik akan menjadikan hasil belajar yang tepat sasaran.

Oemar Hamalik, secara lebih jelas mengemukakan bahwa cara belajar adalah kegiatan-kegiatan yang dilaksanakan sesuai dengan situasi belajarnya, misalnya kegiatan-kegiatan dalam mengikuti pelajaran, menghadapi ulangan/ ujian dan sebagainya (Oemar Hamalik, 1994: 38). Dengan memiliki cara belajar yang baik, nanti akan terasa bahwa setiap usaha belajar selalu memberikan hasil yang sangat memuaskan dan ilmu yang dipelajari dapat dikuasai sehingga ujian dapat dilakukan dengan berhasil. Cara belajar siswa yang dilakukan sama saja dengan cara yang dilakukan peserta didik di sekolah.

Hasil angket siswa ditemukan sebagian kecil siswa yang membiarkan saja materi yang belum dipahami.Sebagian besar siswa tidak melakukan hal demikian. Siswa telah berusaha mencari tahu terhadap materi yan belum dipahami siswa harus konsentrasi dalam belajar supaya berhasil dalam belajar. Pikiran tidak boleh buyar dalam belajar. Dari hasil angket yang dijawab siswa ternyata masih ada siswa yang sering buyar pikirannya dalam belajar. Hal ini tentu saja akan merugikan siswa tersebut dalam belajar. Belajar akan terganggu oleh pikiran yang buyar. Namun demikian, sebagian besar siswa jarang buyar pikirannya dalam belajar bahkan terdapat siswa yang tidak pernah buyar pikirannya dalam belajar. Untuk memudahkan siswa dalam mengulang pelajaran, diperlukan kegiatan membaca ringkasan pelajaran. Hasil angket, menunjukkan bahwa masih cukup banyak siswa yang tidak melakukan hal demikian. Namun demikian, sebagian besar siswa sering dan selalu membaca ringkasan mata pelajaran tersebut.

Cara belajar siswa yang diharapkan adalah mengerjakan tugas/latihan yang diberikan guru di madrasah.Hasil angket menunjukkan bahwa masih ada sebagian kecil siswa yang tidak mengerjakan tugas/latihan di madrasah. Hal tersebut tentu saja akan merugikan siswa. Namun demikian, sebagaian besar 
84 Instructional Development Journal (IDJ), Vol. 1, No. 2, Desember 2018, Hal. 81-87

siswa mengerjakan tugas/latihan di madrasah tersebut. Cara belajar yang baik antara lain adalah belajar rutin dalam menghadapi ujian. Hasil angket siswa diperoleh data bahwa ada sebagian kecil siswa yang tidak belajar rutin.Akan tetapi, sebagian besar siswa sudah belajar rutin dalam menghadapi ujian.

Dalam menghadapi ujian, tentu saja siswa diharapkan melengkapi semua peralatan yang diperlukan menghadapi ujian. Walaupun demikian harapannya, namun masih ditemukan bahwa sebagian kecil siswa tidak mempersiapkannya.Sebagian besar siswa sudah mempersiapkan peralatan dalam menghadapi ujian. Dalam menjawab ujian, seharusnya memahami soal sebelum menjawab ujian. Hasil angket ternyata sebagian kecil siswa jarang dan tidak pernah melakukan hal tersebut. Akan tetapi, sebagian besar selalu dan sering memahami soal sebelum menjawab ujian. Bagi siswa yang dapat memahami soal dengan baik, tentu akan dapat menjawab ujian secara baik. Dalam menjawab ujian, tentu diharapkan dengan tenang. Ketenangan dalam ujian akan memudahkan siswa menjawab ujian secara baik. Data angket diperoleh bahwa ada sebagian kecil siswa selalu dan sering tergesa-gesa dalam menjawan ujian. Namun demikian, sebagian besar siswa ternyata jarang dan bahkan tidak pernah tergesa-gesa dalam menjawab ujian. Dengan demikian, dapat dikatakan bahwa sebagian besar siswa telah belajar secara baik.

Salah satu cara siswa yang baik dalam menjawab ujian adalah memulai menjawab soal yang dirasakan mudah. Dengan cara demikian siswa akan bersemangat menjawab ujian tersebut. Data angket yang diperoleh, ternyata hanya sebagian kecil siswa yang melakukan demikian. Bahkan sebagian besar siswa selalu dan sering menjawab soal ujian tidak memulai dari soal yang dianggap mudah. Dalam mengikuti ujian, seharusnya siswa tidak meninggalkan ruangan ujian seandainya waktu masih ada walaupun soal ujian telah selesai dijawab. Siswa seharusnya mengecek ulang jawaban terhadap soal ujian tersebut. Dengan melakukan cek ulang diharapkan jawaban ujian yang masih ragu-ragu akan menjadi jawaban yang benar. Oleh karena itu, selagi waktu masih ada diharapkan membaca kembali jawaban soal terutama yang masih diragukan kebenarannya.Hasil angket siswa diperoleh data bahwa sebagian besar siswa jarang melakukan hal demikian. Dengan kata lain, selama ini kebanyakan siswa salah dalam taktik mengikuti ujian. Hal ini jelas akan merugikan siswa tersebut.

Adakalanya siswa terganggu belajar apabila mendengar suara bunyi-bunyian. Hal ini terlihat dari data angket bahwa sebagian besar siswa merasa terganggu belajarnya bila mendengarsuara bunyi-bunyian. Sebagian kecil yang merasa tidak pernah terganggu. Apabila siswa konsentrasi dalam belajar, tentu saja suara bunyibunyian tidak akan mengganggu bahkan menjadikan siswa lebih nyaman belajar. Hampir seluruh siswa merasa senang belajar jika menggunakan gambar yang dapat dilihat oleh siswa.Dengan demikian, siswa kebanyakan memilki tipe visual. Secara umum dapat dikatakan bahwa sebagian besar siswa sudah belajar secara baik. Dalam belajar diperlukan pula media dalam bentuk benda bergerak. Media bergerak akan dapat memperjelas pesan atau materi pelajaran yang akan disampaikan guru kepada siswa. Hasil angket siswa diperoleh data bahwa hampir semua siswa merasa tidak terganggu dengan media tersebut.Hanya segelintir siswa saja yang merasa terganggu belajar jika menggunakan media benda-benda bergerak.

Dalam mempelajari ilmu diharapkan sampai tuntas. Dengan demikian, ilmu yang diperoleh akan menjadi menjadi utuh sehingga siswa memilki wawasan yang luas. Dari data angket ternyata masih banyak siswa yang jarang mempelajari ilmu pengetahuan sampai tuntas.Walau demikian, banyak pula siswa yang mempelajari ilmu sampai tuntas. Agar siswa dapat berhasil belajar dengan baik maka seharusnya siswa mempelajari materi pelajaran sebelum ujian. Hal ini sudah dilakukan oleh siswa MTs Negeri Kota Pekanbaru. Hal ini dapat dilihat dari hasil angket bahwa sebagian besar siswa selalu dan sering mempelajari materi pelajaran sebelum mengikuti ujian. Walau demikian, ada sebagian kecil siswa jarang dan tidak pernah mempelajari pelajaran sebelum mengikuti ujian.

Untuk mendapatkan prestasi yang tinggi diperlukan ketekunan dalam belajar. Hasil angket siswa diperoleh data bahwa hamper semua siswa belajar tekun agar mencapai prestasi tinggi. Ada sebagian kecil saja siswa yang jarang melakukan belajar dengan tekun. Dengan demikian, dapat dijelaskan bahwa sebagian besar siswa sudah melakukan cara yang tepat dalam mencepai prestasi yang tinggi. Untuk mendapatkan kesempurnaan tugas, perlu dilakukan cara antara lain berdiskusi dengan teman. Hasil angket siswa diperoleh data bahwa masih banyak siswa yang jarang berdiskusi dengan teman untuk kesempurnaan tugas. Namun demikian, sebagian besar 
siswa sering dan selalu berdiskusi dengan teman untuk mencapai kesempurnaan tugas. Dengan demikian, dapat dikatakan bahwa sebagian besar siswa sudah melakukan cara yang tepat dalam mencapai kesempurnaan tugas.

Persaingan dalam belajar adalah suatu hal yang diperlukan. Oleh karena itu, siswa harus berjuang untuk memenangkan persaingan tersebut. Hasil angket siswa diperoleh data bahwa sebagian besar siswa selalu dan sering memenangkan persaingan dalam belajar. Akan tetapi, ada pula sebagian kecil siswa yang tidak pernah melakukannya. Dengan demikian, dapat dinyatakan bahwa sebagian besar siswa telah melakukan cara yang tepat dalam belajar. Kadangkala muncul kendala yang menghambat pencapaian prestasi belajar. Oleh karena itu, siswa harus mengasi kendala tersebut.Hasil angket diperoleh data bahwa masih ada sebagian kecil siswa membiarkan saja kendala yang menghambat pencapaian prestasi belajar.Walau demikian, sebagian besar siswa sudah mengatasinya.

Siswa yang baik adalah siswa yang selalu mendiskusikan tugas dengan teman, tidak hanya sekedar ngobrol yang tidak tentu arah.Hasil angket siswa diperoleh data bahwa masih banyak siswa yang jarang mendiskusikan tugas dengan temannya. Namun demikian, sebagian besar siswa lebih suka berdiskusi tentang tugas bersama temannya. Siswa yang baik, tentu tidak akan kecewa dengan nilai rendah. Hasil angket siswa ternyata sebagian besar siswa merasa kecewa mendapat nilai tinggi. Hanya sedikit yang tidak merasa kecewa.Seharusnya siswa tidak kecewa, tetapi lebih giat lagi berusaha untuk mendapakan nilai tinggi. Dengan demikian, cara belajar siswa dari sisi ini termasuk keliru. Siswa yang baik adalah siswa yang tertantang untuk mengerjakan soal yang dianggap sulit. Hasil angket siswa ternyata hamper separoh siswa yang jarang bahkan tidak pernah tertantang untuk mengerjakan soal yang dianggap sulit oleh temannya. Dengan demikian, dapat dikatalkan bahwa masih banyak siswa yang tidak baik cara belajarnya. Siswa yang memiliki semangat tinggi dalam belajar, tidak akan menjadi malas jika ada teman yang menyainginya dalam belajar. Siswa seharusnya semakin giat belajar sehingga dapat menjadi yang terbaik dibandingkan temannya. Hasil angket siswa diperoleh data bahwa sebagian besar siswa jarang dan tidak pernah menjadi malas jika ada teman yang menyainginya. Dengan demikian, dapat dikatakan bahwa sebagian besar siswa sudah baik caranya dalam belajar.

Dalam mengerjakan tugas seharusnya siswa mengerjakan dengan sungguh-sungguh sehingga mendapatkan kualitas tugas yang sempurna. Dari hasil angket ternyata separoh dari jumlah siswa yang selalu dan sering mengerjakan tugas hanya seadanya.Separoh lagi dari jumlah siswa mengerjakan tugas dengan serius. Hal ini berarti, bahwa separoh dari jumlah siswa yang tepat cara mengerjakan tugas yang diberikan guru di madrasah. Dalam mengerjakan tugas, seharusnya siswa berupaya maksimal untuk mengerahkan segenap kemampuannya. Akan tetapi dari hasil angket ternyata masih banyak juga siswa yang mengerjakan tugas mengharapkan bantuan pihak lain. Namun demikian, lebih banyak siswa yang telah mengupayakan tugas dengan kemampuan sendiri.

Prestasi belajar siswa merupakan hasil dari proses belajar. Baik buruknya prestasi tersebut tergantung bagaimana proses belajar berlangsung dan tanggapan siswa dari proses tersebut. Apabila proses tersebut berlangsung seperti yang diharap kan tanpa ada gangguan baik internal atau eksternal siswa maka hasil belajar akan berhasil seperti yang diharapkan, dan sebaliknya kalau terdapat gangguan maka hasilnyapun jauh dari harapan. Seperti yang digambarkan atau dipaparkan diatas bahwa salah satu faktor keberhasilan siswa adalah faktor intern, minat siswa terhadap belajar merupakan bagian dari faktor intern. Jadi bila minat siswa terhadap belajar, khususnya biologi tinggi, maka prestasi belajar biologi akan seperti yang diharapkan. Dalam hal ini, juga tidak terlepas dari faktor eksternal yang mempengaruhi minat siswa terhadap biologi, umpanya guru yang mengajar biologi, menarik atau tidak dari segi penampilan, gaya mengajar, pemilihan metode tidak monoton, pengaturan ruang belajar, pemilhan meteri dan sebagainya. Jadi, kalau kita lihat beberpa pendapat diatas bahwa minat dapat mendorong seseorang siswa untuk dapat belajar dengan baik. Siswa yang mempunyai minat belajar yang tinggi akan menghasilkan prestasi belajar yang tinggi pula. Dimana siswa memperlihatkan adanya rasa senang dan melalui mau belajar tanpa ada pengaruh dari siapapun. Karena mereka melakukan semua itu didasari atas niat yang suci dan ikhlas. Dari keterangan di atas dapat disimpulkan bahwa seseorang yang berminat dalam belajar dapat dilihat dalam kegiatan belajarnya, adanya rasa senang, dapat dilihat dari frekwensi belajarnya. 


\section{SIMPULAN DAN SARAN}

\section{Simpulan}

Berdasarkan hasil analisis data yang telah diuraikan pada bab sebelumnya, maka penelitian ini menghasilkan kesimpulan: 1) Hasil penelitian menunjukkan bahwa kualitas minat belajar dan cara belajar siswa secara umum berada pada kategori yang baik; dan 2) Berdasarkan hasil perhitungan diperoleh bahwa nilai signifikansi adalah 0,033 yang lebih kecil dari nilai $a=0,05$ dan nilai $\mathrm{r}_{\text {hitung }}$ adalah $\mathbf{0 , 2 6 3 *}$ pada kategori "sedang". Harga koefisien tersebut selanjutnya diuji signifikansinya dengan membandingkan $r_{\text {tabel }}$ untuk $n=66$ pada taraf $5 \%$ maka $r_{\text {tabel }}=0,254$, di mana nilai $r_{\text {hitung }}>r_{\text {tabel }}(0,236>0,224)$ dan nilai signifikansi yang diperoleh lebih kecil dari 0,05. Dengan demikian, Ha diterima yaitu ada hubungan layanan bimbingan kelompok dengan minat belajar siswa kelas VIII MTs Ash-Shohibiyah Bangun Purba Kabupaten Rokan Hulu Provinsi Riau. Sementara kontribusi cara belajar dalam meningkatkan minat belajar siswa sebesar 11,36\%.

\section{Saran}

Berdasarkan simpulan yang diperoleh dalam penelitian yang penulis laksanakan bahwa antara cara belajar dengan kemampuan mengatasi minat belajar siswa ada hubungan yang positif dan signifikan. Pernyataan di atas mengandung pengertian bahwa cara belajar diperlukan meningkatkan kemampuan mengatasi minat belajar siswa MTs Ash-Shohibiyah Bangun Purba. Dari hasil kenyataan tersebut di atas penulis ingin memberikan masukan yang berupa saran-saran sebagai berikut: 1) Bagi Siswa, hendaklah menerapkan cara belajar yang mengacu pada cara belajar menurut konsep pendidikan Islam, yakni: Meningkatkan tingkat kesiapan belajar, terutama meluruskan niat belajar, motivasi, sikap, minat, dan semangat menuntut ilmu sebagai ibadah jihad; Meningkatkan aktivitas belajar, terutama menyeimbangkan kegiatan belajar ilmu diniyah dan ilmu duniawi, belajar dengan sungguh, memanfaatkan waktu dengan optimal, selalu bermudzakarah, dan bertanya kepada guru untuk mencapai standar kompetensi yang maksimal; Senantiasa mempersiapkan diri menghadapi ulangan harian, sub sumatif, sumatif, dan ujian akhir madrasah, serta ujian nasional; dan Mengembangkan tipe atau model belajar siswa, baik learning to know, learning to do, learning to be, learning to live together, maupun enjoyable learning; 2) Bagi guru, hendaknya memberikan perhatian kepada para siswa yang mengalami minat belajar agar mampu mengatasinya dana bakat yang dimiliki siswa dapat berkembang secara optimal dan prestasi belajarnya meningkat; dan 3) Bagi orang Tua, hendaknya dapat membimbing anaknya dengan member motivasi dan perhatian yang cukup agar anak lebih giat belajar, sehingga anak mampu mengentaskan diri dari kesulitan belajar. Dengan demikian prestasi akan meningkat.

\section{DAFTAR RUJUKAN}

Bahri Djamarah. 2002. Psikologi Belajar. Jakarta: Rineka Cipta.

Dewa Ketut Sukardi. 2003. Manajemen Bimbingan dan Konseling di Sekolah. Jakarta: PT. Bumi Aksara.

Dimyati dan Mudjiono. 2000. Belajar dan Pembelajaran. Jakarta: Rineka Cipta.

Eddy Mungin Wibowo. 1984. Teknik Bimbingan dan Konseling (jilid 1). Semarang: IKIP Semarang.

Hamzah B. Uno. 2008. Teori Motivasi dan Pengukurannya. Jakarta: Bumi Aksara.

Max Darsono, dkk. 2009. Belajar dan Pembelajaran. Semarang: IKIP Semarang Press.

Moh. Nasir. 2005. Metode Penelitian. Jakarta: Ghalia Indonesia.

Muhibin Syah. 2007. Psikologi Belajar. Jakarta: PT Raja Grafindo Persada.

Oemar Hamalik. 2002. Proses Belajar Mengajar. Jakarta: Bumi Aksara.

Prayitno. 2009. Layanan Bimbingan Dan Konseling Kelompok (Dasar Dan Profil)” Jakarta: Ghalia Indonesia.

Sardiman. 2004. Interaksi dan Motifasi Belajar Mengajar. Jakarta: Rajawali Press.

Slameto. 2010. Belajar dan Faktor-Faktor yang memHubunganinya. Jakarta: Rineka Cipta. 
Suciati, dkk. 2004. Belajar dan Pembelajaran 2. Jakarta: Universitas Terbuka.

Sugiyono. 2002. Statistika untuk Penelitian. Bandung: Alfabeta.

Suharsimi Arikunto. 2006. Prosedur Penelitian Suatu Pendekatan Praktek. Jakarta. Rineka Cipta.

Syaiful Sagala. 2010.Konsep dan Makna Pembelajaran. Bandung: Alfabeta.

Tatiek Romlah. 2001. Teori dan Praktek Bimbingan Kelompok. Malang: UNM.

Tatik Romlah. 2001. Teori dan Praktek Bimbingan Kelompok. Malang: Universitas Negeri Malang.

Wina Sanjaya. 2007. Strategi Pembelajaran. Jakarta: Kencana.

Winkel, dan Sri Hastuti. 2006. Bimbingan dan Konseling di Institusi Pendidikan. Yoyakarta: Media Abadi. 